\title{
In vitro effects of methotrexate on peripheral blood monocytes: modulation by folinic acid and $S$-adenosylmethionine
}

\author{
Gideon Nesher, Terry L Moore, Robert W Dorner
}

\begin{abstract}
The mechanism of action of low dose methotrexate in rheumatoid arthritis has not been established. It has been shown to have an anti-inflammatory effect and to inhibit neutrophil chemotaxis, but the effect on monocytes has not been widely studied.

Normal donor peripheral blood monocytes were incubated with methotrexate in vitro and their superoxide production, chemotaxis, and phagocytosis subsequently assessed. Additionally, the influence of different culture media, and of folinic acid, and the methyl donor $\boldsymbol{S}$-adenosylmethionine, and spermidine on the methotrexate mediated effects were evaluated.

It was found that methotrexate in low concentrations inhibited in vitro monocyte chemotaxis and superoxide production but only after prolonged incubation. This inhibition was augmented by. incubation in medium containing a low methionine concentration and was abolished by folinic acid and $S$-adenosylmethionine, suggesting that methotrexate may interfere with specific methylation reactions.
\end{abstract}

The mechanism of action of low dose methotrexate in rheumatoid arthritis has not been defined. Initial studies failed to prove an immune modulating effect, ${ }^{1-3}$ but subsequent studies reported suppression of B cell function, ${ }^{4}$ delayed type hypersensitivity, ${ }^{5}$ IgM rheumatoid factor synthesis, ${ }^{67}$ and mononuclear cell proliferation. ${ }^{7}$ An anti-inflammatory effect was suggested by others. ${ }^{8-10}$ This effect was not related to inhibition of cyclooxygenase or lipoxygenase. ${ }^{10}$ Furthermore, methotrexate inhibited neutrophil chemotaxis in vivo ${ }^{11}$ and ex vivo, ${ }^{12}$ though short in vitro incubations ( 30 minutes) of neutrophils with methotrexate failed to show such inhibition. ${ }^{12}$

Monocytes have a key role in chronic inflammatory conditions such as rheumatoid arthritis. Several slow acting antirheumatic drugs have been shown to modulate monocyte function, ${ }^{13-17}$ which may account, at least in part, for their beneficial effect in rheumatoid arthritis.

The effects of methotrexate on monocyte function have not been studied in detail. We studied in vitro the effects of methotrexate on isolated normal donor blood monocytes and the modulation of these effects by folinic acid and by the methyl donor $S$-adenosylmethionine.

\section{Methods}

SEPARATION OF MONONUCLEAR CELLS

Blood (30 ml) from healthy donors was diluted in $50 \mathrm{ml}$ normal saline, layered over $12 \mathrm{ml}$ Ficoll-Hypaque, and separated by centrifugation at $1200 \mathrm{rpm}$, room temperature, for 30 minutes. Mononuclear cells were collected and washed with RPMI-1640 (Sigma, St Louis, MO), medium-199 (BBL, Cockeysville, MD), or RPMI-1640 medium deficient, supplemented with L-glutamine ( $2 \mathrm{mmol} / \mathrm{l})$, L-leucine $(0.4 \mathrm{mmol} / \mathrm{l})$, L-lysine $(0.2 \mathrm{mmol} / \mathrm{l})$, and $\mathrm{L}$ methionine $(0.03$ or $0.06 \mathrm{mmol} / \mathrm{l}$ ) (all from Sigma).

\section{MONOCYTE SEPARATION AND INCUBATION}

Monocytes were separated by the method of Freundlich and Avdolovic. ${ }^{18}$ Plastic Petri dishes $(60 \times 15 \mathrm{~mm}$; Falcon, Becton-Dickinson, Oxnard, CA) were coated with $5 \mathrm{ml} 2 \%$ gelatin (Sigma) and incubated for two hours at $37^{\circ} \mathrm{C}$. The fluid was then removed and the dishes allowed to dry.

Five millilitres of a mononuclear cell suspension $\left(2 \times 10^{6}\right.$ cells $\left./ \mathrm{ml}\right)$ were added to each Petri dish and incubated for 40 minutes at $37^{\circ} \mathrm{C}$. The non-adherent cells were then removed by gentle suction. Adherent cells were 92 (SEM 3)\% monocytes by latex phagocytosis.

Methotrexate (Sigma) was then added to the adherent cells, diluted in RPMI-1640, RPMI1640 deficient, or medium-199, with $10 \%$ fetal calf serum to final concentrations of $10^{-8}$ to $10^{-5} \mathrm{~mol} / \mathrm{l}$. Controls were incubated in drug free media. Incubation times ranged from one to 64 hours.

The supernatant was then removed by gentle suction and $5 \mathrm{M}$ EDTA (Sigma) in RPMI1640, RPMI-1640 deficient, or medium-199, diluted $1: 1$ in $0.15 \mathrm{M}$ phosphate buffered saline pH 7.3, was added for 10 minutes. After washing, the cells were resuspended in RPMI1640, RPMI-1640 deficient, or medium-199 and incubated at $37^{\circ} \mathrm{C}$ for one hour with various concentrations of folinic acid (Sigma), $S$-adenosylmethionine (Sigma), spermidine (Sigma), or medium alone. The cells were then washed and resuspended in phenol red-free balanced salt solution (Sigma) for the superoxide assay or in RPMI-1640, medium-199, or RPMI-1640 deficient for the chemotaxis assay. Cell viability was evaluated by erythrosin B (Bio-Rad, Richmond, CA) dye exclusion.

\section{MONOCYTE CHEMOTAXIS ASSAY}

Zymosan activated serum was prepared by incubating normal human serum with zymosan 
(Sigma) $(10 \mathrm{mg} / \mathrm{ml})$ for 30 minutes at $37^{\circ} \mathrm{C}$ After removal of the zymosan by centrifugation (2000 rpm for 10 minutes at $4^{\circ} \mathrm{C}$ ) the supernatant was stored at $-70^{\circ} \mathrm{C}$ until used.

One micromole of $N$-formyl-methionyl-leucylphenylalanine (Sigma) or $10 \%$ zymosan activated serum in medium was added to the lower compartments of Boyden chambers. A suspension of monocytes $\left(10^{6} / \mathrm{ml}\right)$ was placed in the upper compartment. The two compartments were separated by a $5 \mu \mathrm{m}$ pore size nitrocellulose filter (Millipore, Bedford, MA). Incubations were carried out at $37^{\circ} \mathrm{C}$ for 90 minutes.

Filters were then removed, fixed in isopropanol, stained with $8 \%$ Giemsa stain, washed in water, dehydrated in $70 \%$ and $100 \%$ isopropanol sequentially, cleared in xylenes, and mounted in Permount. Random migration was determined by measuring migration towards medium alone. Chemotaxis was assayed by the leading front technique, measuring the distance travelled by the two most advanced cells in response to the zymosan activated serum, minus the random migration.

MONOCYTE SUPEROXIDE PRODUCTION ASSAY Opsonised zymosan was prepared by incubating normal human serum with zymosan $(10 \mathrm{mg} / \mathrm{ml})$ for 30 minutes at $37^{\circ} \mathrm{C}$. Opsonised zymosan was removed after centrifugation $\left(2000 \mathrm{rpm}\right.$ at $4^{\circ} \mathrm{C}$ for 10 minutes), washed, resuspended in phenol red-free balanced salt solution, and stored at $-70^{\circ} \mathrm{C}$ until used.

Superoxide production was measured by reduction of cytochrome $c$. Reaction mixtures contained $2 \times 10^{5}$ monocytes $/ \mathrm{ml}$ phenol red-free balanced salt solution, opsonised zymosan ( 2 $\mathrm{mg} / \mathrm{ml})$, and cytochrome $c(2 \mathrm{mg} / \mathrm{ml})$ (Sigma), with or without superoxide dismutase $30 \mathrm{U} / \mathrm{ml}$ (Sigma). Catalase (1000 U/ml, Sigma) was also added as oxidation of cytochrome $c$ by hydrogen peroxide may underestimate superoxide production. ${ }^{19}$ Controls included reaction mixtures without cells and mixtures without stimulants.

Incubations were carried out at $37^{\circ} \mathrm{C}$ for 30 minutes. The extent of cytochrome $c$ reduction in the supernatant was measured as the change in absorbance at $550 \mathrm{~nm}$ against controls (reaction mixtures without cells) which was inhibited by superoxide dismutase. The molar extinction coefficients of ferricytochrome $c$ and ferrocytochrome $c\left(8.9 \times 10^{3}\right.$ and $29.9 \times 10^{3}$ $\mathrm{M}^{-1} \mathrm{~cm}^{-1}$ respectively) were used in the calculations.

STATISTICAL ANALYSIS

Assays were performed in duplicate. Results are

Table 1 Effect of methotrexate on monocyte chemotaxis toward $10 \%$ zymosan activated serum. Results are given as percentages (SEM) versus controls at one hour*

\begin{tabular}{lclllll}
\hline $\begin{array}{l}\text { Methotrexate } \\
\text { concentration } \\
\text { (molll) }\end{array}$ & \multicolumn{6}{l}{ Time of preincubation with methotrexate $(h)$} \\
\cline { 2 - 7 } & 1 & 6 & 16 & 40 & 64 \\
\hline $10^{-5}$ & $97(1)$ & $80(5) \dagger$ & $45(10) \dagger$ & $41(10) \dagger$ & $11(8)$ \\
$10^{-6}$ & $101(3)$ & $91(3)$ & $78(8)$ & $38(3) \dagger$ & $3(2) \dagger$ \\
$10^{-7}$ & $103(5)$ & $91(23)$ & $83(4)$ & $78(6)$ & $21(3)$ \\
$10^{-8}$ & $99(2)$ & $98(2)$ & $90(2)$ & $76(3)$ & $30(4)$ \\
0 & $100(5)$ & $98(5)$ & $96(6)$ & $92(8)$ & $51(18)$ \\
\hline
\end{tabular}

$* 100 \%=68 \mu \mathrm{m}$, by the leading front method (see text).

tp $<0.05 v$ control without methotrexate. the means of three to eight assays. The significance of the difference between the means was evaluated by Student's $t$ test.

\section{Results}

CELL VIABILITY AND FUNCTION

Cell viability and function were checked after the incubation period by the erythrosin $B$ exclusion assay. Adherent cell viability was $>90 \%$ after incubations of up to 40 hours. A significant decrease in cell viability was noted at 64 hours' incubation (42 (SEM 12)\% viability). Cell viability was not significantly affected by methotrexate in concentrations of $10^{-8}$ to $10^{-5}$ $\mathrm{mol} / \mathrm{l}$.

Random migration, chemotaxis, and superoxide production were likewise affected by the duration of incubation, showing good function during the initial 40 hours of incubation but deterioration of these functions with more prolonged incubations (tables 1, 2, and 3).

\section{EFFECT OF METHOTREXATE ON MONOCYTE} RANDOM MIGRATION

Random migration was decreased by $25 \%$ after preincubation for $\mathbf{4 0}$ hours with methotrexate at $10^{-6}$ and $10^{-5} \mathrm{~mol} / \mathrm{l}$, but this did not reach statistical significance. Lower methotrexate concentrations did not affect random migration.

\section{EFFECT OF METHOTREXATE ON MONOCYTE} CHEMOTAXIS

Preincubations with methotrexate at $10^{-8}$ and $10^{-7} \mathrm{~mol} / \mathrm{l}$ did not affect monocyte chemotaxis. At $10^{-6} \mathrm{~mol} / \mathrm{l}$ incubations of 40 hours resulted in $60 \%$ inhibition of chemotaxis (table 1). Increasing methotrexate concentration to $10^{-5}$ $\mathrm{mol} / \mathrm{l}$ resulted in more rapid inhibition of chemotaxis $(20 \%$ at six hours, $53 \%$ at 16 hours of preincubation), but the degree of inhibition was still $60 \%$ at 40 hours.

\section{EFFECT OF METHOTREXATE ON MONOCYTE} SUPEROXIDE PRODUCTION

Methotrexate at $10^{-8} \mathrm{~mol} / \mathrm{l}$ did not affect superoxide production (table 2). At $10^{-7} \mathrm{~mol} / \mathrm{l}$ there was minimal suppression $(17 \%$ at 16 hours, $24 \%$ at 40 hours). The inhibition was greater with $10^{-6} \mathrm{M}$ and $10^{-5} \mathrm{M}$ methotrexate, being $64 \%$ and $73 \%$ respectively at 40 hours.

\section{INHIBITION BY METHOTREXATE}

\section{Effect of different media}

We compared the effect of three different culture media on monocyte inhibition by methotrexate: RPMI-1640 containing $2 \cdot 5 \mu M$ folic acid and $100 \mu \mathrm{M}$ methionine, RPMI-1640 methionine deficient (Sigma) supplemented with $30 \mu \mathrm{M}$ or $60 \mu \mathrm{M}$ methionine, and medium199 containing $0.025 \mu \mathrm{M}$ folic acid and $200 \mu \mathrm{M}$ methionine.

There was no significant difference between responses of monocytes incubated in RPMI1640, medium-199, or RPMI-1640 deficient supplemented with $60 \mu \mathrm{M}$ methionine. The 
Table 2 Effect of methotrexate on superoxide production by monocytes. Results are given as percentages (SEM) versus controls at one hour*

\begin{tabular}{lrrlll}
\hline $\begin{array}{l}\text { Methotrexate } \\
\text { concentration } \\
\text { (molll) }\end{array}$ & \multicolumn{6}{l}{ Time of preincubation with } & methotrexate $(h)$ & & \\
\cline { 2 - 6 } & 1 & 6 & 16 & 40 & 64 \\
\hline $10^{-5}$ & $98(4)$ & $86(6)$ & $30(10) \dagger$ & $25(8) \dagger$ & $12(11) \dagger$ \\
$10^{-6}$ & $101(2)$ & $101(2)$ & $78(6) \dagger$ & $33(7) \dagger$ & $13(5) \dagger$ \\
$10^{-7}$ & $99(4)$ & $96(3)$ & $80(3) \dagger$ & $70(8) \dagger$ & $30(8)$ \\
$10^{-8}$ & $105(4)$ & $98(4)$ & $88(2)$ & $79(5)$ & $41(5)$ \\
0 & $100(5)$ & $101(4)$ & $96(2)$ & $92(6)$ & $67(16)$ \\
\hline
\end{tabular}

${ }^{*} 100 \%=4 \cdot 8 \mathrm{nmol}$ reduced cytochrome $c / 10^{\circ}$ monocytes $\times 30$ minutes.

$\mathrm{tp}<0.05 v$ control at respective incubation times.

Table 3 Effect of different media on inhibition of monocyte functions by methotrexate after 40 hours' incubation at $10^{\circ} \mathrm{mol} / \mathrm{l}$. Results are given as percentages (SEM) versus controls (monocytes incubated for 40 hours without methotrexate)

\begin{tabular}{lllll}
\hline Monocyte function & RPMI-1640 & Medium-199 & $\begin{array}{l}\text { RPMI-1640 } \\
\text { deficientt }\end{array}$ & $\begin{array}{l}\text { RPMI-1640 deficientf } \\
+10+\text { M methionine }\end{array}$ \\
\hline Chemotaxis & $55(5)$ & $61(9)$ & $41(3) \S$ & $84(10) \|$ \\
Superoxide production & $58(7)$ & $64(8)$ & $35(7) \varnothing$ & $83(5) \|$ \\
Phagocytosis & $89(6)$ & $90(2)$ & $87(5)$ & $82(10)$ \\
\hline
\end{tabular}

${ }^{*} 100 \%=63 \mu \mathrm{m}$ (chemotaxis) and $4.4 \mathrm{nmol}$ reduced cytochrome $c / 10^{6}$ monocytes $\times 30$ minutes (superoxide production).

tContaining $3 \times 10^{-5} \mathrm{M}$ methionine.

$\ddagger$ Methionine was added for one hour after $\mathbf{4 0}$ hours' incubation with methotrexate.

s $<<0.05 v$ cells in RPMI-1640.

$\| \mathrm{p}<0.05 v$ cells in RPMI-1640 deficient.

degree of inhibition by methotrexate was not affected by changing the culture medium. When the cells were incubated in RPMI-1640 deficient medium supplemented with $30 \mu \mathrm{M}$ methionine, however, slightly increased inhibitory effects of methotrexate on both chemotaxis and superoxide production were noted, which were reversible with addition of $10^{-4} \mathrm{~mol} / \mathrm{l}$ methionine (table 3). Addition of glutamine at $10^{-3} \mathrm{~mol} / \mathrm{l}$, cysteine, serine, or glycine at $10^{-4}$ $\mathrm{mol} / \mathrm{l}$, however, did not significantly affect the methotrexate mediated inhibition. Consequently, all incubations were carried out in this medium.

\section{Effect of different stimulants}

There was no significant difference between the chemotactic responses to zymosan activated serum and to $N$-formyl-methionyl-leucylphenylalanine. The degree of inhibition by methotrexate was similar after either stimulation (data not shown).

\section{METHOTREXATE INHIBITION OF CHEMOTAXIS AND SUPEROXIDE GENERATION}

Effect of folinic acid

Adherent mononuclear cells were incubated for 40 hours with $10^{-6} \mathrm{M}$ methotrexate, then washed and incubated with folinic acid at $10^{-8}-10^{-4} \mathrm{~mol} / \mathrm{l}$ for one hour before chemotaxis and superoxide generation assays. Folinic acid at $10^{-6}$ to $10^{-4} \mathrm{~mol} / \mathrm{l}$ reversed the inhibition by methotrexate, whereas lower concentrations had no effect (tables 4 and 5).

\section{Effect of S-adenosylmethionine}

Adherent mononuclear cells were incubated for 40 hours with $10^{-6} \mathrm{M}$ methotrexate, then washed and incubated with $S$-adenosylmethionine at $10^{-8}$ to $10^{-4} \mathrm{~mol} / \mathrm{l}$. Reversal of the inhibition by methotrexate was achieved at $S$-adenosylmethionine concentrations of $10^{-6}$ to $10^{-4} \mathrm{~mol} / \mathrm{l}$, whereas lower concentrations were less effective (tables 4 and 5). $S$-adenosylmethionine itself did not significantly affect chemotaxis or superoxide production.

\section{Effect of spermidine}

To determine whether the effect of $S$-adenosylmethionine is mediated through increased synthesis of polyamines we incubated the cells with spermidine at $10^{-8}$ to $10^{-4} \mathrm{~mol} / \mathrm{l}$ for one hour before the chemotaxis and superoxide production assays. As spermidine can be oxidised to aldehydes and hydrogen peroxide, catalase was added to some of the cultures at $1000 \mathrm{U} / \mathrm{ml}$. Spermidine had no significant effect at any of the concentrations tested (tables 4 and 5).

\section{Discussion}

These results showed that methotrexate in concentrations up to $10^{-5} \mathrm{~mol} / \mathrm{l}$ did not change random migration of normal peripheral blood

Table 4 Effect of folinic acid, S-adenosylmethionine, and spermidine on methotrexate inhibition of monocyte chemotaxis. Results are given as percentages (SEM) versus controls (monocytes incubated for 40 hours in culture medium alone)*

\begin{tabular}{lllllll}
\hline & \multicolumn{5}{l}{ Concentration of S-adenosylmethionine/spermidinelfolinic acid (molll) } \\
\cline { 2 - 7 } & 0 (methotrexate alone) & $10^{-8}$ & $10^{-7}$ & $10^{-6}$ & $10^{-5}$ & $10^{-\dagger}$ \\
\hline Methotrexate $+S$-adenosylmethionine & $41(3)$ & $62(2) \dagger$ & $68(2) \dagger$ & $68(10) \dagger$ & $84(5) \dagger$ & $92(3) \dagger$ \\
Methotrexate+spermidine & $41(3)$ & $49(3)$ & $53(6)$ & $49(5)$ & $60(8)$ & $60(10)$ \\
Methotrexate+folinic acid & $41(3)$ & $50(3)$ & $48(4)$ & $66(3) \dagger$ & $80(4) \dagger$ & $87(6) \dagger$
\end{tabular}

${ }^{*} 100 \%=63 \mu \mathrm{m}$ by the leading front method (see text).

tp $<0.05 v$ cells in methotrexate alone.

Table 5 Effect of folinic acid, $S$-adenosylmethionine, and spermidine on methotrexate inhibition of monocyte superoxide production. Results are given as percentages (SEM) versus controls (monocytes incubated for 40 hours in culture medium alone)*

\begin{tabular}{lllllll}
\hline & \multicolumn{5}{l}{ Concentration of S-adenosylmethionine/spermidinelfolinic acid (mol/l) } \\
\cline { 2 - 7 } & 0 (methotrexate alone) & $10^{-8}$ & $10^{-7}$ & $10^{-6}$ & $10^{-5}$ & $10^{+}$ \\
\hline Methotrexate $+S$-adenosylmethionine & $36(7)$ & $30(6)$ & $41(3)$ & $63(5) \dagger$ & $73(12) \dagger$ & $92(6) \dagger$ \\
Methotrexate + spermidine & $36(7)$ & $35(3)$ & $30(3)$ & $29(5)$ & $47(9)$ & $56(13)$ \\
Methotrexate+folinic acid & $36(7)$ & $39(2)$ & $44(6)$ & $60(4) \dagger$ & $54(8) \dagger$ & $85(11) \dagger$ \\
\hline
\end{tabular}

${ }^{*} 100 \%=4 \cdot 4 \mathrm{nmol}$ reduced cytochrome $c / 10^{6}$ monocytes $\times 30$ minutes.

tp $<0.05 v$ cells in methotrexate alone. 
monocytes. Methotrexate inhibited monocyte chemotaxis and superoxide production in vitro, however. These effects were dependent on time and concentration. They were noted at $10^{-6}$ and $10^{-5} \mathrm{~mol} / \mathrm{l}$ concentrations of methotrexate and prolonged incubation periods. This is in agreement with a previous study ${ }^{17}$ showing that 30 minute in vitro incubations inhibited monocyte chemotaxis only at methotrexate concentrations of $10^{-4}$ and $10^{-3} \mathrm{~mol} / \mathrm{l}$, whereas lower concentrations were not inhibitory. The importance of the time factor was also shown by the lack of methotrexate effect on neutrophil chemotaxis after short (30 minutes) in vitro incubations. ${ }^{12}$

Low dose pulse methotrexate results in peak serum concentrations at $10^{-6} \mathrm{~mol} / 1$, with trough concentrations below $10^{-8} \mathrm{~mol} / 1 .^{20}$ The inability to show significant effect of methotrexate at this low concentration in our in vitro system raised the question as to whether such an effect on monocytes occurs in vivo. Although the answer to this is not apparent, evidently some important parameters in vitro are different in vivo. One such variable is the concentration of folic acid, which is 100 -fold greater in RPMI-1640 than in the serum. Increased folate may interfere with the methotrexate effect owing to competition on the membrane receptor site, or on the enzyme dihydrofolate reductase. Moreover, methotrexate influx and efflux in cells may differ in vivo and in vitro. ${ }^{21}$ Possibly, the noted in vitro anti-inflammatory effects of methotrexate are achievable in vivo at lower concentrations with continual use.

This question of relevancy of the in vitro data to the in vivo situation might have been answered by an ex vivo study performed on monocytes of patients with rheumatoid arthritis treated with methotrexate alone. As the current recommended treatment for rheumatoid arthritis requires a combination of drugs, however, starting and maintaining patients with methotrexate alone for the sole purpose of this study was not feasible.

The inhibitory effects of methotrexate were reversed by addition of folinic acid, suggesting that inhibition of chemotaxis and superoxide production is mediated through inhibition of generation of reduced folates.

The methotrexate inhibitory effects were augmented by incubation in culture medium containing a low methionine concentration. This was reversed by addition of methionine and also by $S$-adenosylmethionine, and was dependent on concentration. The ability of $S$ adenosylmethionine to enter cells has been questioned because of its polarity. A recent study, however, reported doubling of $S$ adenosylmethionine content in L1210 cells incubated with $5 \times 10^{-4} \mathrm{M} S$-adenosylmethionine. ${ }^{22}$ To evaluate whether the protective effect of $S$-adenosylmethionine is mediated through generation of polyamines we added spermidine to the cultures after the incubation with methotrexate. In contrast with $S$-adenosylmethionine, spermidine did not reverse the methotrexate effects on monocytes. Although polyamines (especially in high concentrations, $10^{-4} \mathrm{~mol} / \mathrm{l}$ ) can modulate leucocyte responses to stimuli, ${ }^{23-25}$ we found no such effect with the concentrations tested. These combined data suggest that methotrexate may also inhibit methylation reactions dependent on $S$-adenosylmethionine.

Methylation reactions may have a role in the chemotactic and oxidative responses of monocytes. ${ }^{26-28}$ Generation of certain methyl donors might be affected by methotrexate. It primarily inhibits the generation of reduced folates through inhibition of dihydrofolate reductase, ${ }^{29}$ and it may secondarily inhibit the synthesis of $S$ adenosylmethionine. $S$-adenosylmethionine is synthesised from methionine. In the cell methionine is regenerated from homocysteine, a reaction which requires both methionine synthase, methyl cobalamine, and methyl tetrahydrofolate, which is dependent on dihydrofolate reductase. ${ }^{30}$ In addition to interference with intracellular methionine synthesis, methotrexate may also inhibit methionine transport into the cell. ${ }^{31}$

We are not aware of any report on the effect of methotrexate on $S$-adenosylmethionine synthesis, but additional indirect evidence suggests such an effect. Rats given nitrous oxide, which inhibits regeneration of methionine through inhibition of methylcobalamine and methionine synthase, had lower tissue concentrations of both methionine and $S$-adenosylmethionine. ${ }^{32}$ In this context it is of interest to note that nitrous oxide was reported to augment methotrexate toxicity in vivo ${ }^{33}$ and to decrease neutrophil chemotaxis. ${ }^{34}$ Furthermore, after methotrexate treatment patients had increased plasma and urine homocysteine concentrations $^{35}$ and decreased plasma methionine, ${ }^{34}$ suggesting inhibition of methionine synthesis.

These data support the hypothesis that methotrexate has anti-inflammatory effects. ${ }^{8-10}$ We suggest that by inhibiting formation of methyl donors, such as reduced folates and, possibly, $S$-adenosylmethionine, methotrexate may inhibit methylation dependent processes that are essential for the inflammatory response.

Supported in part by a fellowship grant from the Lupus Foundation of America, Eastern Missouri Chapter (Dr Nesher), and grants from the Employees Charity Services of McDonnellDouglas Corporation of St Louis, and Eastern Missouri Chapter of the Arthritis Foundation.

1 Anderson P A, West S G, O'Dell J R, Via C S, Claypool R G Kotzin B L. Weakly pulse methotrexate in rheumatoid arthritis. Clinical and immunological effects in a randomized double-blind study. Ann Intern Med 1985; 103: 489-96.

2 Thompson R N, Watts C, Edelman J, Esdaile J, Russell A S. A controlled two-centre trial of parenteral methotrexate therapy for refractory rheumatoid arthritis. $\mathcal{J}$ Rhewmatol 1984; 11: 760-3.

3 Weinblatt M E, Coblyn J S, Fox D A, et al. Efficacy of lowdose methotrexate in theumatoid arthritis. $N$ Engl $\mathcal{Y}$ Med 1985; 312: 818-22

4 Rosenthal G J, Weigand G W, Germolec D R, Blank J A, Luster $M I$. Suppression of B-cell function by methotrexate and trimetrexate. F Immenol 1988; 141: 410-6.

5 O'Callaghan J W, Bretscher P, Russell A S. The effect of lowdose chronic intermittent parenteral methotrexate on delayed type hypersensitivity and acute inflammation in a delayed type hypersensitivity and acute infla

6 Olsen N J, Callahan L F, Pincus T. Immunologic studies of rheumatoid arthritis patients treated with methotrexate. rheumatoid arthritis patients treatc

7 Olsen N J, Murray L M. Anti-proliferative effects of methotrexate on peripheral blood mononuclear cells. Arthritis Rhewe 1989; 32: 378-85.

8 Segal R, Mozes E, Yaron M, Tartakovsky B. The effects of methotrexnte on the production and activity of interleukin-1. Arthritis Rhewe 1989; 32: 370-7.

9 Hays S, Garrett I R, Vernon-Roberts B, Cleary E G, Manthey 
B, Brooks P M. Influence of prednisolone and methotrexate on cellular and biochemical aspects of acute and chronic inflammation studied in subcutaneously implanted sponges in rats. $\mathcal{R}$ R sumat 1986; 13: 1007-13.

10 Welles W L, Silkworth J, Oronsky A L, Kerwar S S, Galivan J. Studies on the effect of low-dose methotrexate on rat adjuvant arthritis. $\mathcal{f}$ Rheumatol 1985; 12: $904-6$.

11 Suarez C R, Pickett W C, Bell D H, McClintock D K, Oronsky A L, Kerwar S S. Effect of low-dose methotrexate on neutrophil chemotaxis induced by leukotriene $B_{4}$ and complement C5a. I Rheromatol 1987; 14: 9-11.

12 O'Callaghan J W, Forrest M J, Brooks P M. Inhibition of neutrophil chemotaxis in methotrexate-treated rheumatoid arthritis patients. Rhewmatol Int 1988; 8: 41-5.

13 Hurst N P, Bell A Nuki G. Studies of the effect of D-penicillamine and sodium aurothiomalate therapy on superoxide anion production by monocytes from patients
with rheumatoid arthritis: evidence for in vivo stimulation with rheumatoid arthritis: evidence for in vivo st

14 Ho P P K, Young A L, Southard G L. Methyl ester of $\mathrm{N}$-formyl-methionyl-leucyl-phenylalanine. Chemotactic responses of human blood monocytes and inhibition of gold compounds. Arthritis Rhewm 1978; 21: 133-6.

15 Walker J R, Smith M J H, Ford-Hutchinson A W. Antiinflammatory drugs, prostaglandins, and leucocyte migration. Agents Actions 1976; 6: 602-6.

16 Rinehart J J, Balcerzak S P, Sagone A L, LoBuglio A F. Effect of corticosteroids on human monocyte function. E Clin Invest 1974; 54: 1337-45.

17 Norris D A, Weston W L, Sams W M Jr. The effect of immunosuppression and anti-inflammatory drugs on immunosuppression and anti-inflammatory drugs on monocyte

18 Freundlich B, Avdolovic N. Use of gelatin/plasma coated flasks for isolating human peripheral blood monocytes. f Immunol Methods 1983; 62: 31-7.

19 Arthur M J P, Kowalski-Saunders P, Gurney S, Tolcher R, Bull F G, Wright $R$. Reduction of ferricytochrome $C$ may underestimate superoxide production by monocytes. f Immunol Methods 1987; 98: 63-9.

20 Edelman J, Biggs D F, Jamali F, Russell A S. Low dose methotrexate kinetics in arthritis. Clin Pharmacol Ther 1984; 35: 382-6.

21 Goldman I D, Matherly L $H$. The cellular pharmacology of methotrexate. Pharmacol Ther 1985; 28: 77-102.

22 Guarnieri C, Georgountzos A, Caldarera I, Flamigni F,
Ligabue A. Polyamines stimulate superoxide production in human neutrophils activated by N-fMet-Leu-Phe, but not humol myristate acetate. Biochim Biophys Acta 1987; 930: phorbo.

23 Kafy A M L, Haigh C G, Lewis D A. In vitro interaction between the endogenous polyamines and superoxide anion Agents Actions 1986; 18: 555-9.

24 Ferrante A. Inhibition of human neutrophil locomotion by the polyamine oxidase-polyamine system. Immunolog 1985; 54: 785-90.

25 Pick E, Mizel D. Role of transmethylation in the elicitation of an oxidative burst in macrophages. Cell Immunol 1982; 72: 277-85.

26 Pike M C, Kredich N M, Snyderman R. Requirement of Sadenosyl-L-methionine-mediated methylation for human monocyte chemotaxis. Proc Natl Acad Sci USA 1978; 75: 3928-32.

27 Pike M C, Snyderman R. Transmethylation reactions regulate affinity and functional activity of chemotactic factor receptors on macrophages. Cell 1982; 28: 107-14

28 Jackson R C. Biological effects of folic acid antagonists with antineoplastic activity. Pharmacol Ther 1984; 25: 61-82.

29 Metthews R G. Methionine biosynthesis. In: Blakley R L Benkovic S J, eds. Folates and pterins. Vol 1 . New York: Wiley Interscience, 1984: 497-554.

30 Scanlon K J, Berkowitz K, Pallai M E, Waxman S. Inhibition of methionine transport by methotrexate in mitogen stimulated human lymphocytes. Cancer Treatment Reports 1983; 67: 631-9.

31 Vina J R, Davis D W, Hawkins R A. The influence of nitrous oxide on methionine, $\mathrm{S}$-adenosylmethionine, and other amino acids. Anesthesiology 1986; 64: 490-5.

32 Goldhirsch A, Gelber R D, Tattersall M N H, Rudenstan C M, Cavalli F. Methotrexate/ $\mathrm{N}_{2} \mathrm{O}$ toxic interaction in perioperative chemotherapy for early breast cancer. Lance 1987; ii: 151 .

33 Nunn J F, O'Morain C. Nitrous oxide decreases motility of human neutrophils in vitro. Anesthesiology 1982; 56: 45-8.

34 Broxson E H, Stork L C, Allen R H, Stabler S P, Kolhouse J F. Changes in plasma methionine and total homocysteine levels in patients receiving methotrexate infusions. Cancer Res 1989; 49: 5879-883.

35 Refsum H, Ueland P M, Kvinnsland S. Acute and long-term effects of high-dose methotrexate treatment on homocysteine in plasma and urine. Cancer Res 1986; 46: 5385-91. 